\title{
Los Comentarios Reales del Inca Garcilaso, según un manuscrito anónimo obras citadas de 1613: aspectos filológicos y discursivos ${ }^{*}$
}

\section{Los Comentarios Reales of Inca Garcilaso, according to an anonymous manuscript of 1613: philological and discussion aspects}

\author{
ROSARIO NAVARRO GALA \\ Universidad de Zaragoza. Facultad de Filosofía y Letras. \\ Departamento de Lingüística General e Hispánica. \\ Correo electrónico: rosnagal@unizar.es
}

Existe un temprano resumen de los Comentarios Reales del Inca Garcilaso, fechado a primeros de junio de 1613, entre los manuscritos atesorados por el padre de Ávila y conservados hoy en la Biblioteca Nacional de España, el cual, hasta la fecha, no ha sido prácticamente estudiado. En este trabajo se intenta demostrar, entre otras cosas, que dicho manuscrito fue escrito por Francisco de Ávila, así como descubrir los motivos que pudieron llevar a su autor a realizar un extracto de la obra garcilasiana. Resumen que parece dar inicio a un nuevo tipo textual: la reseńa o recensión científica. Para realizar esta tarea se adopta una perspectiva interdisciplinar que permite arrojar luz sobre aspectos de este manuscrito que de otra manera pasarían inadvertidos.

Palabras clave: tradiciones discursivas, discurso referido, español en América, siglo XVII.

There is an early summary of the Royal Commentaries of the Inca Garcilaso, dated at the beginning of June 1613, among the manuscripts treasured by the father of Ávila and preserved today in the National Library of Spain, which, to date, has not been practically studied. In this work we try to demonstrate, among other things, that the manuscript was written by Francisco de Ávila, as well as

\footnotetext{
*Este trabajo se ha realizado con el apoyo del Proyecto de investigación I+D+i. Programa Estatal de Fomento de la Investigación Científica y Técnica de Excelencia del Ministerio de Economía y Competitividad FFI201563878-C2-1-P.

Un primer esbozo del presente estudio fue presentado al Congreso Internacional 1609-2009: IV Centenario de los Comentarios Reales de los Incas, realizado en el Cuzco el año 2009. Agradezco a Esperanza López Parada y a todos aquellos que han realizado una lectura atenta de este artículo las sugerencias que me han realizado y que espero haber sabido aprovechar.
} 
discover the reasons that could lead the author to make an extract of the Garcilasian work. Summary that seems to start a new textual type: the review or scientific review. To carry out this task, an interdisciplinary perspective is adopted, which allows us to shed light on aspects of this manuscript that would otherwise go unnoticed.

Key words: discursive traditions, referred discourse, Spanish in America, XVII century.

\section{INTRODUCCIÓN}

La recepción de los Comentarios Reales entre los coetáneos americanos del Inca Garcilaso es un capítulo todavía por escribir. Se sabe, no obstante, que el 28 de febrero de 1612 pasó la censura española un lote de 159 libros dirigidos a Cristóbal Cacho de Santillana, fiscal de la Audiencia de Lima; entre estos libros se hallaba un ejemplar de los Comentarios Reales del Inca Garcilaso (González Sánchez 2010: 31-33). Asimismo, el propio Garcilaso dio noticia del traslado a América de algunos ejemplares en su Historia General del Perú. En esta obra, cuenta el escritor mestizo que fray Jerónimo de Oré, antes de marchar hacia América le hizo una visita en Córdoba y le pidió algunos ejemplares de sus libros. De este modo, en el equipaje de los frailes, hubieron de llegar a América tres ejemplares de La Florida y cuatro de los Comentarios (Guibovich 1990-1992; 2016: 50).

La existencia de una reseña a los Comentarios Reales del Inca Garcilaso es prueba inequívoca del gran interés que, muy poco tiempo después de su publicación, despertó esta obra entre la nueva sociedad letrada hispana en el Perú colonial; esta sociedad incluía, claro es, tanto a espańoles que de manera permanente u ocasional se habían trasladado a las provincias ultramarinas como a criollos, mestizos e indígenas hispanizados. La fuente que utilizó el padre extirpador de idolatrías para realizar dicha reseña sigue siendo un misterio. Tal vez tuviera acceso al mencionado ejemplar del fiscal Cristóbal Cacho de Santillana, aunque no necesariamente debemos pensar en un acceso al libro impreso, pues, muy posiblemente, la difusión de la obra garcilasiana no se limitó a su versión impresa, sino que, junto a ella, debió de circular, de manera más o menos íntegra, a través de copias manuscritas, tal y como había sido frecuente a lo largo de la Edad Media ${ }^{1}$. El mencionado resumen, fechado en 1613, consta de tres folios (61r.-63v.) que sintetizan la historia de los incas y sus descendientes y forma parte del Ms 3169 conservado en la Biblioteca Nacional de España.

\footnotetext{
${ }^{1}$ Esta situación se prolongó, al menos, hasta finales del siglo XVIII. Por ejemplo, de las descripciones geográficas del virreinato del Perú, realizadas por el aragonés Cosme Bueno entre los años 1768-1776, se conservan hoy dos copias manuscritas de la época. Una en el Archivo de la Biblioteca de la Real Academia de la Historia, publicada por Serrera/Vila/Hernández (1996), y otra copia, a lo que parece ya perdida, en la Biblioteca Memoria Prado de Lima, publicada por Valcárcel (1951).
} 


\section{EL RESUMEN DE LOS COMENTARIOS REALES (MS. 3169 BNE): SU CONTENIDO}

El manuscrito 3169 de la Biblioteca Nacional española contiene una serie de documentos, conocidos desde hace años ${ }^{2}$, que se ocupan, en lo fundamental, de la época prehispánica andina. Este singular mamotreto, caracterizado en palabras de la doctora López Parada como hipertexto mestizo (López Parada 2009), incluye entre sus manuscritos el antes citado resumen de los Comentarios Reales. El resumen comienza con el relato de los acontecimientos o hitos que permitieron la llegada de los españoles al Perú, con indicación del nombre y origen geográfico de los personajes que intervinieron en ellos. El inicio de la historia se sitúa en 1484, con Alonso Sánchez, natural de Huelva y su fortuita llegada (a causa de una tormenta) a Santo Domingo, de cuyo descubrimiento dejó noticia al genovés Colón. El siguiente hito tiene lugar el año 1513; se trata del descubrimiento del Mar del Sur por -dice su autor- Blasco (Vasco) Núñez de Balboa, natural de Xerez, de Badajoz, y la llegada de uno de sus navíos en 1515 a Perú, nombre este que, señala, tomaron sin más fundamento que la respuesta de un indio que pescaba en el río. Termina este párrafo con una enumeración de obras que trataron antes que la de Garcilaso el tema del incanato; en dicha enumeración se observa una significativa ausencia respecto de su fuente, a saber, ha desaparecido de dicha enumeración la obra Repúblicas del mundo del padre agustino fray

\footnotetext{
${ }^{2}$ Una primera descripción del contenido de este legajo puede verse en Paz (1933). Muy conocido es el contenido del mencionado volumen. Realizo, a continuación, un rápido repaso: la copia de las relaciones de Molina y Polo de Ondegardo, el texto quechua, conocido como la Relación de Huarochirí, la inconclusa y comentada traducción del mismo, la relación de Pachacuti Yamqui y los tres folios que contienen un resumen de parte de los Comentarios Reales. Constituye un caso peculiar la última plana del manuscrito de Huarochirí, el folio 114 vuelto, en el que se lee una petición muy breve, realizada en 1663, a favor de Francisco Miranda y relacionada con un pleito. La pluma que escribió esta pequeña nota de un solo folio de extensión y letra suelta y grande es la misma que señaló en el folio 91 de la Relación de Huarochirí: «De la mano y pluma de Thomas», indicando así la autoría de la copia de dicha relación o, al menos de una parte de ella. ¿Quién escribió esta pequeña nota? Solo podemos, de momento, proponer hipótesis. El legajo pudo estar, tras la muerte de Ávila, en poder del fraile agustino Miguel de Aguirre, uno de sus albaceas y receptor de los 45 volúmenes manuscritos que Ávila poseía en su biblioteca. Se sabe que dicho fraile agustino llegó a Madrid en 1652, de modo que muy bien pudo traer con él la colección de manuscritos avilianos. Fuera como fuere, la mencionada nota da fe de que en 1663 dicha colección de manuscritos había llegado ya a España, pues en ella se cita a un Francisco de Miranda y a Thomás de Montesinos, este último, depositario general de la ciudad de Sevilla. Es extraño que dicha nota haya pasado inadvertida para muchos investigadores, si bien Taylor, ante la imposibilidad de determinar un autor concreto, atribuye la redacción de los ritos y tradiciones de Huarochirí a Thomás: "El autor-llamémoslo Tomás-" (Taylor 2008: 10), autoría que también le fue atribuida por Duviols (1966). Tal vez la generalización de dicho olvido se deba a que aporta información que podría contradecir la fecha de copia generalmente atribuida al manuscrito de Huarochirí, pues la persona que en uno de sus folios reconoce al escribano que ha realizado la copia es la misma que escribe la nota, y ambas anotaciones las realiza en fecha tan tardía como 1663. No obstante, en mi opinión, la existencia de la mencionada nota no debe, obligatoriamente, dar al traste con las supuestas fechas de redacción y/o copia de dicho manuscrito -aunque plantea una duda muy razonable que hay que tener inexcusablemente en cuenta-. Pese a la menciona objeción, muy bien podría ser que quien reconoce la letra de Tomás, pese a encontrarse en Espańa en 1663, no haga sino reconocer y señalar, en un texto anterior a la redacción de la nota misma, la letra de uno de los colaboradores de Ávila.
} 
Jerónimo Román y Zamora. Tras la enumeración de los autores españoles que trataron el tema de Perú, se ofrece una somera descripción del País, en la que Ávila interviene para realizar numerosos cambios respecto de las distancias establecidas por Garcilaso en su obra. Por ejemplo, señala que "desde Arica a la Provincia Laricosa tiene 50 leguas», mientras que Garcilaso las cifró en sus Comentarios en 70 leguas. Tras la descripción del Perú comienza, bajo el título "Origen y sucessión de los yngas», la narración de algunas leyendas sobre el origen de estos y emprende la tarea de relatar su sucesión, recogiendo los nombres de los incas, de sus mujeres e hijos, así como de las hazañas que acometieron durante sus respectivos mandatos. La sucesión de los incas incluye el mestizaje producido entre los conquistadores españoles y las elites indígenas, a lo que el autor del resumen añade información actualizada. Solo inserta dos cuestiones culturales que, para más exactitud, son adelantos técnicos que permitieron la expansión del imperio inca: el puente de crisneja y el puente destinado a cruzar el río Desaguadero; ambas construcciones propiciaron la conquista de Chayanta.

De este modo, el autor del resumen refiere el discurso garcilasiano, suprimiendo y añadiendo aquellas referencias que cree oportunas para llegar a una sintética historia del Perú incaico, entendida esta como un continuum histórico. Queda enlazada la historia de los incas con la de los espańoles, por el providencial hallazgo de la isla de Santo Domingo, que acabará propiciando un discurrir conjunto de la historia de los incas y de los espańoles. Esto se pone de manifiesto por alianzas que van más allá de pactos puntuales al cimentarse en el mestizaje físico entre la elite del imperio recién descubierto y los conquistadores, conducidos hasta él por la mano de dios. De hecho, en los últimos párrafos se amplía la información que aportan los Comentarios Reales respecto de la descendencia inca, mezclada ya con sangre española, reelaborando de este modo la historia del Perú con la incorporación de sus propios conocimientos, forzosamente más cercanos a la realidad peruana de la época que la que ofrece el ilustre Garcilaso tras tantos años en la Península. Por ejemplo, señala que la mujer noble española con quien casó don Carlos Inca se llamaba María y deja un espacio en blanco para escribir más tarde el apellido que no parece recordar en el momento de redacción ${ }^{3}$. Añade, también, el autor del resumen, que Carlos Melchor ynca "casó con hija de Pedro Alonso Carrasco, del hábito de Santiago, vezino del Cozco”. Véase:

El Atahuallpa nunca passó de/36 Ssaussa, i desde (.) allí mandaua (-). No quedó cassi casta destos yngas a lo menos de/37 el último Rey (-), aunque es uerdad que quedaron dos auquis que son ynfante, $/^{1}$ el vno llamado Paullu (-), el otro Titu (-). El Paullu tuuo un hijo que $/ 2$ se dixo don Carlos Inca, casó con vna señora española, dońa maría de [deja un espacio en blanco] tuuo <por $>$ hijo en ${ }^{3}$ ella, que fue don Carlos Melchor ynga (.). Este casó con hija de Pedro Alonso carrasco, $/{ }^{4}$ del hábito

\footnotetext{
${ }^{3}$ No todo espacio hallado en un manuscrito indica, sin más, que el manuscrito es una copia. Para determinar el carácter de copia de un manuscrito es necesario analizar con detenimiento el texto completo. Suelen ser signos de copia la repetición de palabras, de sílabas, la supresión de sintagmas, la confusión entre sílabas próximas, etc.
} 
de San tiago, vezino del cozco. Año de 1602 passó a españa, al prin- $/ 5$ cipio del año de 1604 (.) se le hizo merced de 7500 ducados de renta en la caja de/ $/ 6$ lima (.), y ayuda de costa para traer su mujer a españa (.) y vn hábito de Santiago. $/^{7}$ De el Titu no se sabe ahora si ay decendencia (.-). De las nustas, yn- $/ 8$ fantas hijas de huayna capac (.), la una tuuo se llamó doña Beatriz coya, $/^{9}$ casó con martín de Bustinca, contador de la caja Real de cozco (-). Otra, $/{ }^{10}$ Doña leonor Coya (.), casó con Juan Badía (-), y $2^{a}$ uez con Francisco de villacastín. $/^{11}$ El Rey atahuallpa uuo en el cozco un hijo (.) y dos hijas: en las quales $/{ }^{12}$ uuo la vna se dezía doña Angelina, en esta uuo el marqués don francisco Piçarro $/{ }^{13}$ vn hijo que se llamó don francisco Piçarro $\mathrm{y}<$ una $>$ hija doña Francisca Piçarro, uuo en $/{ }^{14}$ vna hija de huayna capac, llamada doña ynés huayllas nusta. Con esta doña francisca $/{ }^{15}$ fue casado Hernando Piçaro, su tío. (=-) La Dońa ynés huayllas nusta casó/ ${ }^{16}$ después con martín de anpuero, vezino de Lima (-). La otra hija se dezía ${ }^{17}$ doña Beatriz/ o dońa ysabel, casó con Blas gómez, estremeño (.), $2^{\mathrm{a}} \mathrm{vez} /{ }^{18}$ con Sancho de Rojas (-). El hijo se dezía don francisco Atahuallpa, era $/{ }^{19}$ hermosísimo, murió muy moco, fols. 63r. y v.

\section{LA AUTORÍA GRÁFICA DEL RESUMEN DE LOS COMENTARIOS REALES}

A continuación, se analizará desde un punto de vista paleográfico el manuscrito citado, a fin de intentar determinar la autoría del mismo. Dicho análisis se verá reforzado por el estudio de los usos ortográficos practicados en el texto, tales como el empleo de grafías propias del sistema fonético-fonológico del español medieval o el respeto que muestra al uso de las grafías cultistas dobles. Asimismo, se analizará otro aspecto de interés, ahora, de trascendencia fonética, los lapsus cálami que de manera coadyuvante nos ponen sobre la pista de la autoría del manuscrito.

\subsection{Algunas cuestiones paleográficas del resumen de los "Comentarios Reales"}

Como es bien sabido, cuando un documento carece de rúbrica, la adscripción del mismo a un autor determinado se mueve, siempre, en el terreno de la hipótesis. Tampoco están libres de este afán algunos documentos rubricados, pues puede ocurrir, por ejemplo, que el copista firme con el nombre del emisor. Ninguno de los manuscritos que componen el legajo 3169 de la Biblioteca Nacional española está firmado, pese a que se haya señalado lo contrario ${ }^{4}$. No obstante, podemos intentar adscribir las distintas grafías a quien, sabemos,

\footnotetext{
${ }^{4}$ En efecto, entre los muchos aciertos de Duviols (1966: 14) se le deslizó al agudo investigador el error de considerar que el "Tratado y relación de los errores, falsos dioses y otras supersticiones y ritos..." de Francisco de Ávila exhibía la firma del Padre extirpador de idolatrías al final del mismo; no obstante, lo que se aprecia al final de dicho manuscrito es un adorno semejante, en algo, a una rúbrica, pero no la firma de Ávila. En cambio, aunque sin ofrecer explicación alguna, sí acertó, en mi opinión, al atribuir a Francisco de Ávila la autoría del resumen de los Comentarios Reales. Véase, asimismo, el trabajo de Martínez (2016).
} 
compiló los documentos, Francisco de Ávila, pues contamos para ello con una carta rubricada por él mismo, conservada en el Archivo General de Indias, que nos servirá para determinar, analizando los ducti y otras cuestiones anexas, si se corresponde con la letra de alguno de estos manuscritos recopilados por el Padre extirpador de idolatrías.

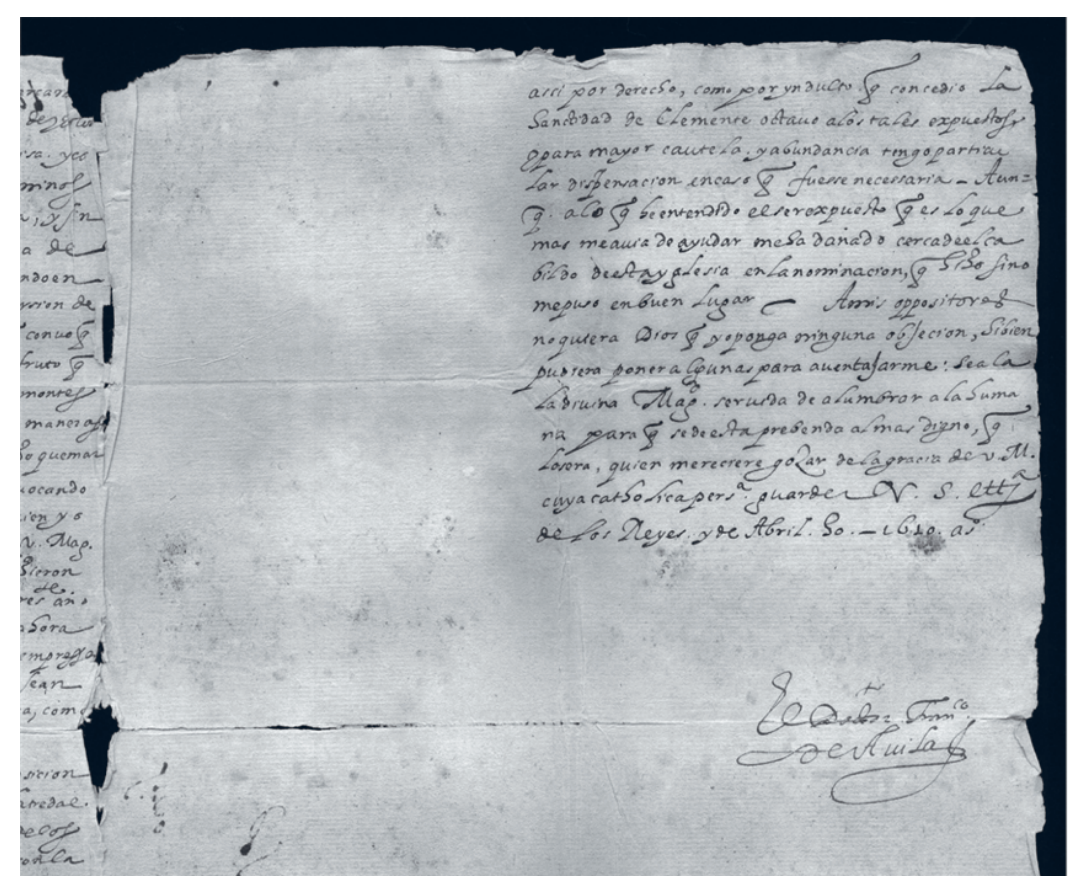

Figura 1. Carta de letra y firma de Francisco de Ávila. AGI, Lima 325, fol. 2r.

La tarea, obviamente, es muy compleja pues la época que nos ocupa se caracteriza por un marcado polimorfismo gráfico y esto dificulta, aún más, la adscripción de un documento a su autor. Sin embargo, hemos podido atribuir la letra del resumen de los Comentarios del Inca Garcilaso a Francisco de Ávila, pese a que en un primer acercamiento a dichos folios la letra parece distar de la de su carta autógrafa. 


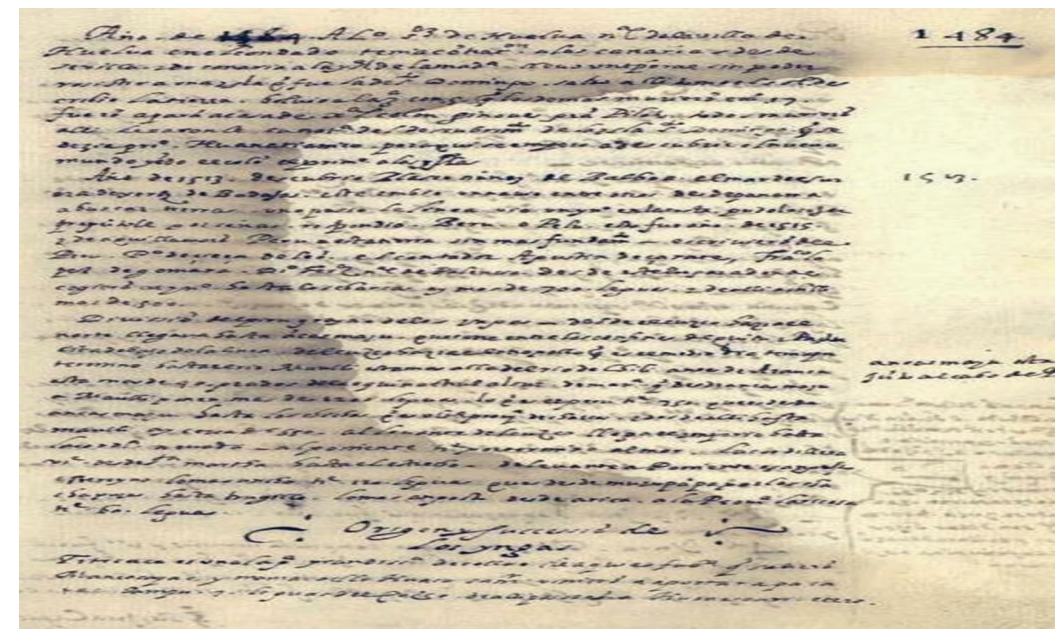

Figura 2. Folio 61r. del resumen de los Comentarios Reales del Inca Garcilaso

Pocas dudas caben, en cambio, en cuanto a la autoría del primer folio de las relaciones de Cristóbal de Molina y de Polo de Ondegardo, donde se aprecia meridianamente la letra de Francisco de Ávila.
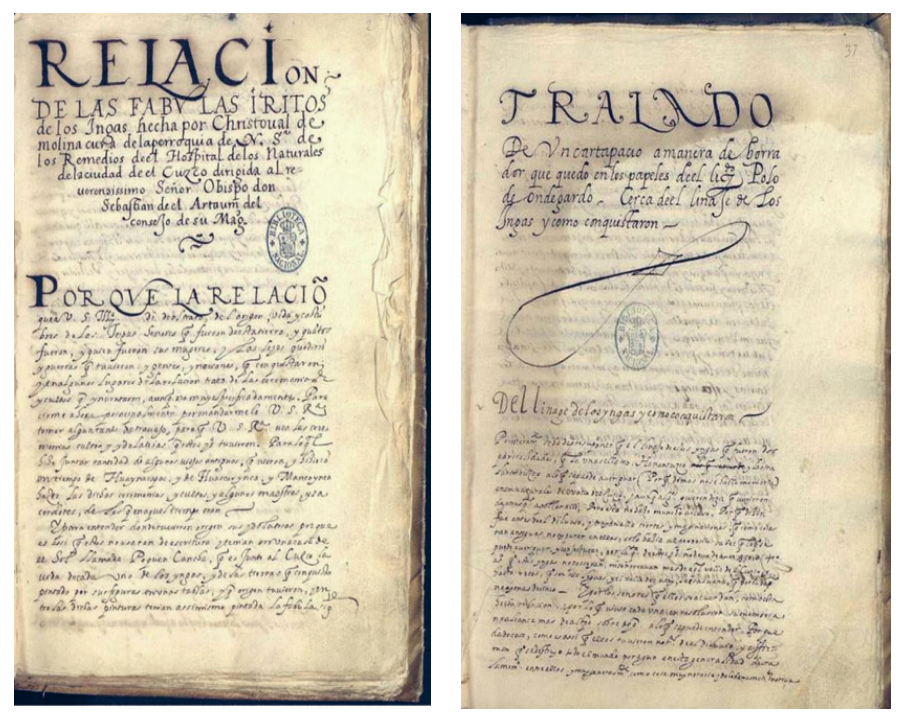

Figuras 3 y 4 
Asimismo, se ve con claridad en algunas anotaciones al margen, halladas en los manuscritos de Huarochirí, de Molina, de Polo de Ondegardo y de Joan de Santa Cruz. Casos aparte son el "Tratado y relación de los errores..." y el resumen de los Comentarios Reales. En efecto, el "Tratado y relación...”, pese a lo señalado por Duviols (1966), no fue escrito en su totalidad por la pluma de Francisco de Ávila, aunque sí en su mayor parte. Desde el capítulo 6 y casi hasta el final del manuscrito, toma la pluma un segundo escribiente, en concreto, desde la última línea del fol. 12r. hasta el folio $14 \mathrm{v}$.

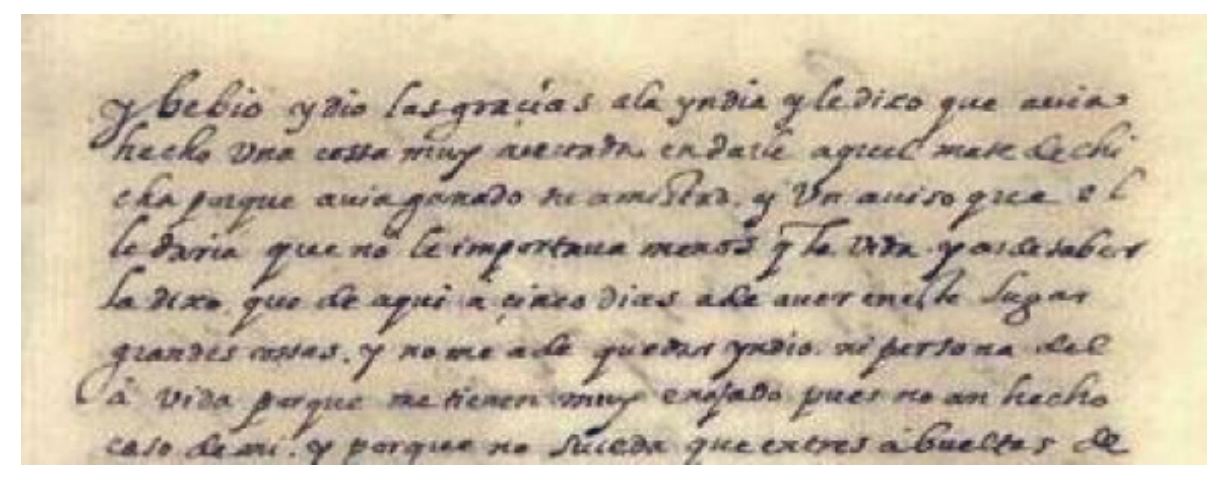

Figura 5. Letra de autor anónimo, fol. 13r.

Son, pues, de autoría de Ávila los folios del 1r. al 12r., la última línea del folio 14v. y el folio 15 r.

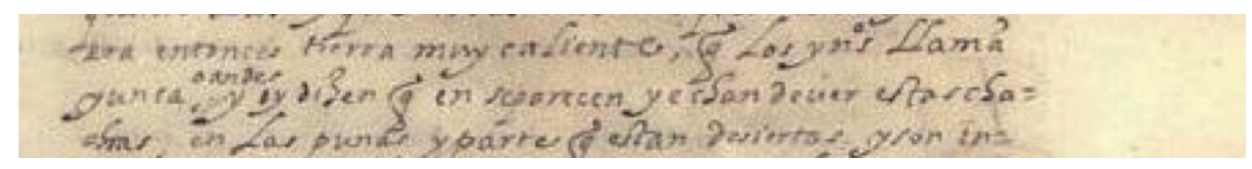

Figura 6. Letra de Francisco de Ávila, fol. 2r.

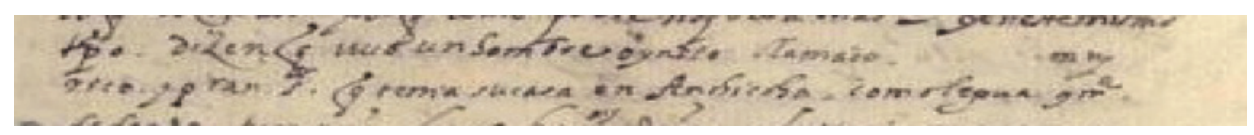

Figura 7. Letra de Francisco de Ávila, fol. 8r. 
El resultado del estudio de las grafías viene avalado por el análisis lingüístico de dicho tratado, ya que el segundo escribiente se muestra laísta en el empleo de los pronombres átonos de tercera persona: "y la dixo con muy amorossas y tiernas palabras ... y él la respondió”, fol. 13v. En cambio, el mencionado rasgo posiblemente dialectal no se encuentra en ninguno de los escritos atribuidos al Padre cuzqueño. La existencia de laísmo en este fragmento, en el que la letra, hemos visto, cambia de manera evidente, revela, asimismo, que la función de este segundo escribiente no fue la de tomar al dictado o copiar, sino la de traducir del quechua al castellano.

El cotejo de los manuscritos del resumen con la carta autógrafa de Ávila pone de manifiesto la autoría aviliana del resumen de los Comentarios Reales, pues la semejanza se observa en las grafías, pero también en la separación regular que deja su autor entre las distintas letras que componen cada palabra, cuestión esta última, asimismo, relevante a la hora de determinar la autoría de un texto escrito. No obstante, ya lo hemos visto, el resumen en un primer vistazo podría parecer que se aleja de la caligrafía de Ávila, pues se encuentra contenido en tres folios escritos con letra pequeńa y apretada, lo que hace que, por ejemplo, la inclinación hacia la derecha, propia de los escritos avilianos, no se produzca de manera regular hasta las últimas líneas, que es cuando los escribientes suelen relajarse, avistando ya el fin de su texto.

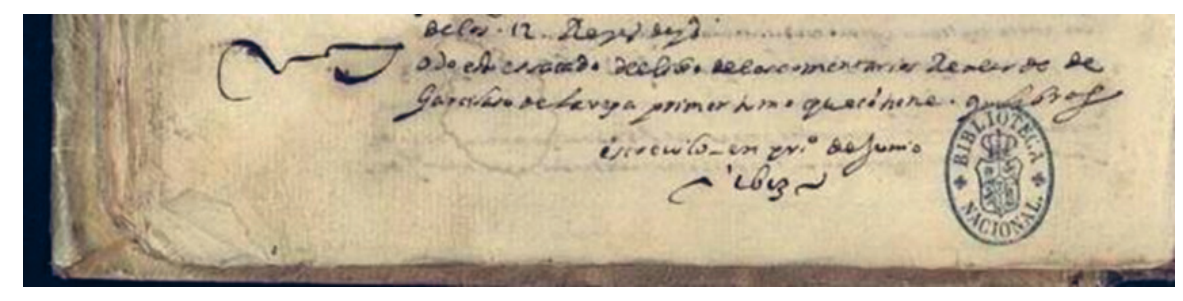

Figura 8. Final del resumen de los Comentarios Reales

Junto con la escasa inclinación se podría pensar que ciertas grafías alejan el escrito de las costumbres gráficas de Ávila. En efecto, las aparentes diferencias gráficas entre su carta autógrafa y este resumen, así como la escasa inclinación de la escritura, han llevado a la crítica a considerar que este manuscrito no fue escrito por Ávila, pero si se cotejan detalladamente los diferentes textos que han salido de su pluma, se observa que todas estas grafías se hallan igualmente en los escritos de indudable autoría aviliana. Por ejemplo, el peculiar trazo de la $q$, que observamos en el resumen y que no vemos en la carta autógrafa (solo un folio y medio), se halla, verbigracia, en el "Tratado falsos...” de Ávila. 


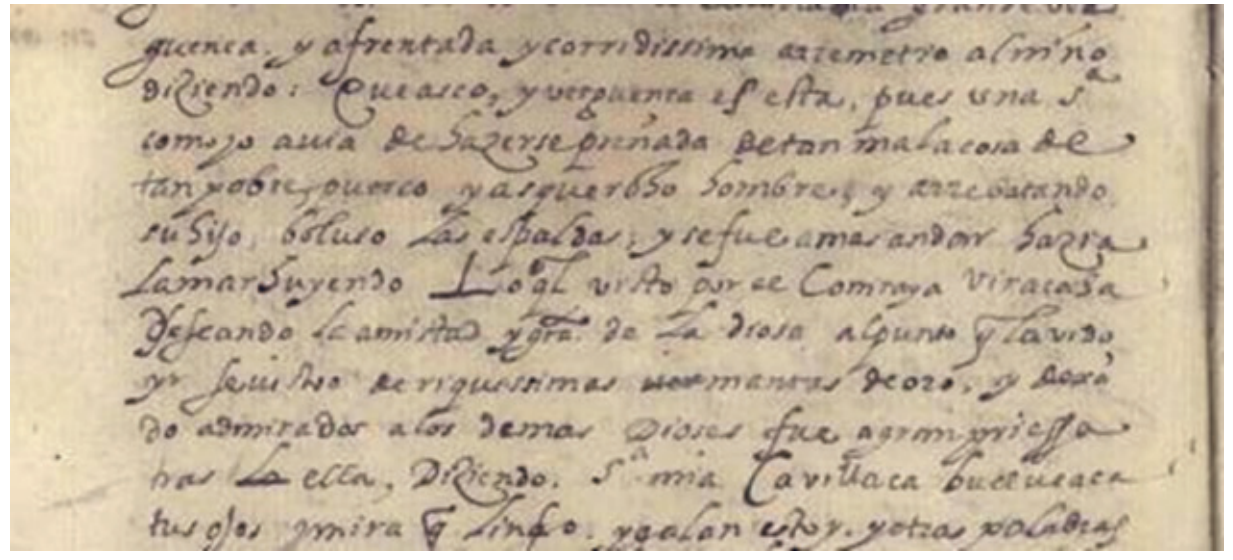

Figura 9. "Tratado...". Obsérvese la q en la línea 2 "diziendo: qué asco"

El resumen presenta también grafías que son, en todo, compatibles con las propias de la carta autógrafa, tales como la $z$, la $t$ mayúscula, la $h$, etc.

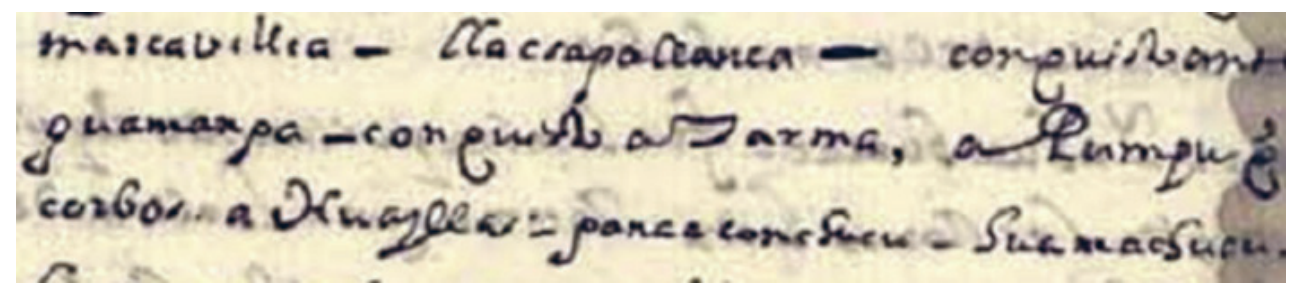

Figura 10. Obsérvense las grafías $t$ [Tarma], la $q$ [conquista],

la $h$ [huamachucu...], $g$ [guamanga], en fragmento del resumen de los Comentarios Reales

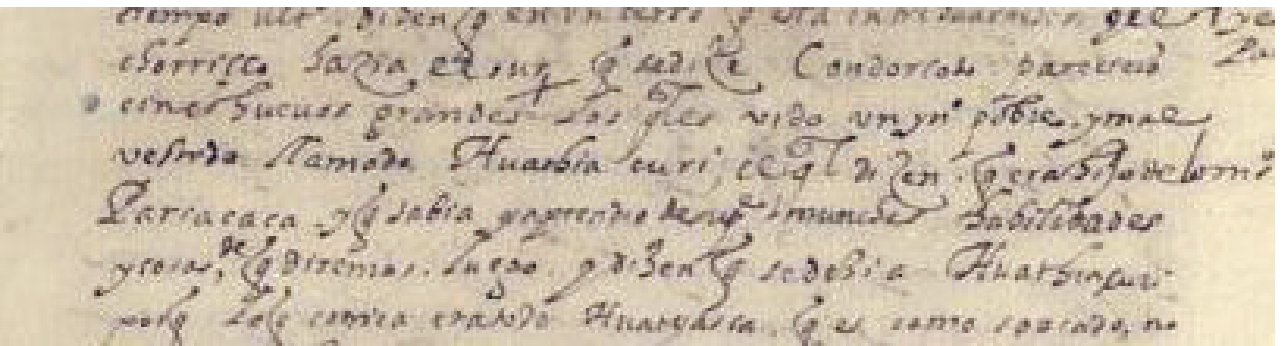

Figura 11. "Tratado..." Obsérvese la hache mayúscula y minúscula, la $t$, el polimorfismo en la $z$, etc. 


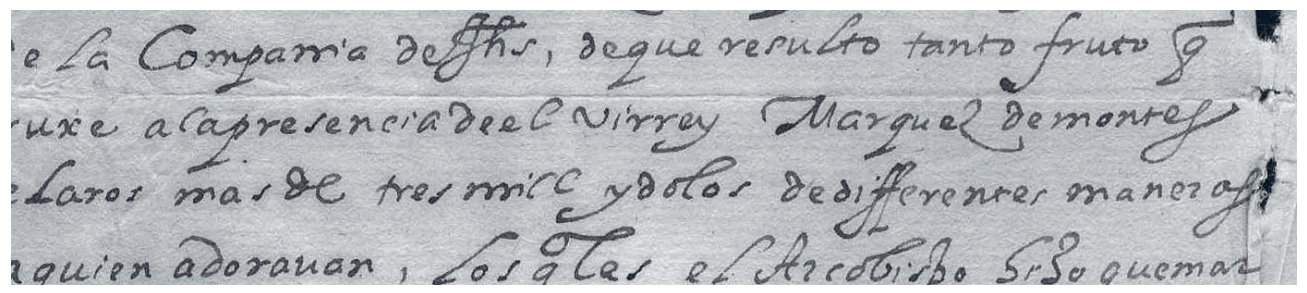

Figura 12. Carta autógrafa, folio 1v.

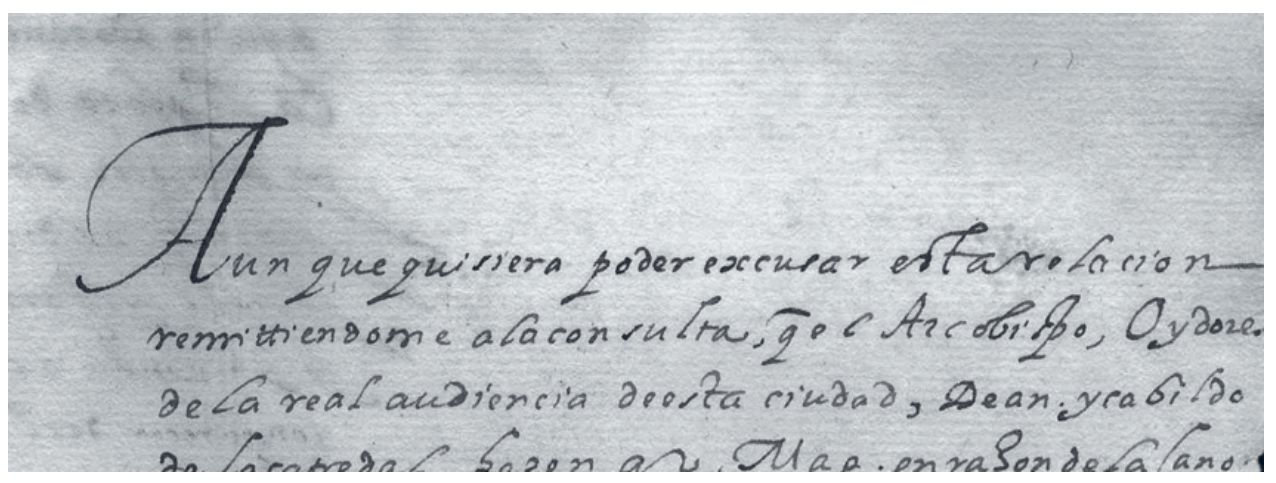

Figura 13. Carta autógrafa, folio 1r. Véase, junto a otras grafías, el trazo de la $A$ mayúscula y compárese con la misma letra en la figura 7

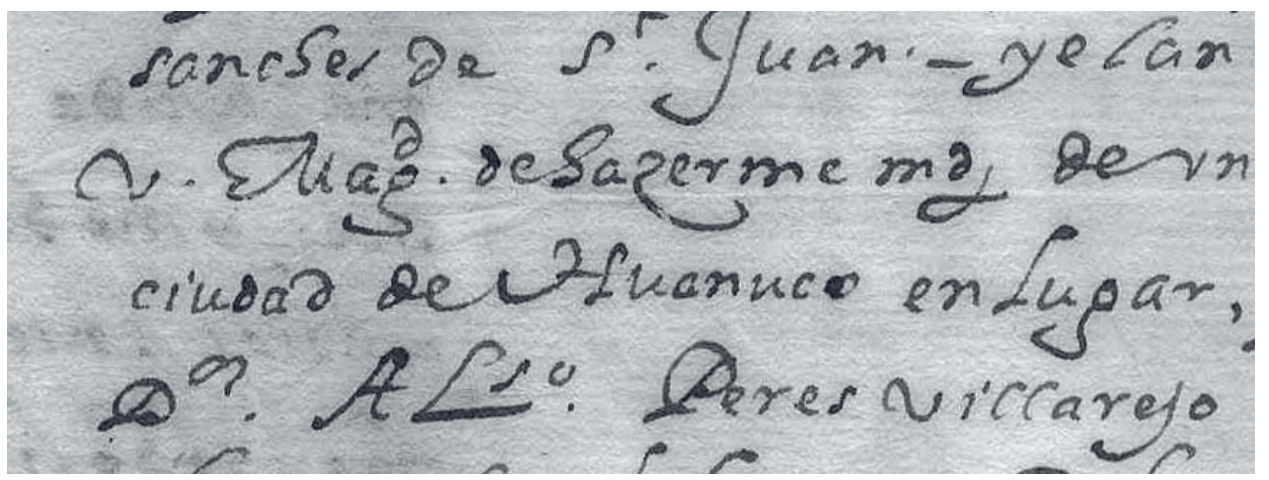

Figura 14. Carta autógrafa, folio 1r. Obsérvese, entre otras, la grafía de h en Huanuco

De modo que, pese al polimorfismo gráfico practicado por el autor, el análisis de los ducti nos permite proponer la autoría de Francisco de Ávila. 


\subsection{El estudio ortográfico del resumen de los "Comentarios Reales"}

La época a la que pertenece el manuscrito, principios del siglo XVII, se caracteriza por la coexistencia de dos corrientes ortográficas de distinto signo. La corriente etimologizante, que pretendía el empleo de la ortografía tradicional, y la fonetista, que buscaba adaptar la escritura a la pronunciación, si bien lo habitual era la irregularidad ortográfica, incluso entre aquellos que propugnaban una ortografía fonetista, como Nebrija o Mateo Alemán. No será hasta la aparición, en 1726, del primer tomo del Diccionario de Autoridades cuando, con la creación de la Real Academia, se emprenda, por primera vez, la tarea de renovar y sistematizar la ortografía dotándola de unas reglas que le dieron unidad. En dicha labor encontramos la huella de la tendencia etimologizante, mencionada anteriormente, que seguirá viva durante el siglo ilustrado. Así pues, hoy día, y pese a los intentos de adaptación entre fonética y ortografía que se han venido produciendo, el castellano conserva huellas etimológicas y bivalencias de grafemas heredados del latín 6 .

El estudio de la ortografía de estos folios de Ávila muestra un uso gráfico en el que abundan las grafías conservadoras, si bien su texto no se halla exento de algún rasgo ortográfico innovador.

\subsubsection{Grafias conservadoras}

El empleo de grafía $u$ como consonante bilabial sonora para el imperfecto de indicativo (llegaua f. 61r.), las grafías $v$ y $u$ tanto para la vocal velar (trugillo, 61r. passim) como para la consonante bilabial (uilla, boluió, Sevilla, lleuó, navio, 61r., passim) o el uso de ss (ápico-alveolar sorda) en el imperfecto de subjuntivo (gozassen 63r., llamasse 62r. causasse 62v. desterrasse 63r., pareciesse 63r.) y, con cierta frecuencia, en algunos términos (passaron, cessaron, 61v., sucessión, diuissión 61r., assi 62r., passim). Del mismo modo el autor parece mostrar gusto por las grafías cultistas, pues se leen casos como: chrisnejas 61v., phantasma, 62r., nephando 63r., yllustró, edifficio, 62v., etc.

\subsubsection{Grafias innovadoras}

Son escasos los usos gráficos que detonen una preferencia por las innovaciones ortográficas. Solo cabe destacar la preferencia de $z$ ante las vocales $a, o, u$ (fortaleza 62v.) cuyo empleo, en la época, es rasgo ortográfico de modernidad.

\footnotetext{
${ }^{5}$ No se pretende ofrecer un estudio exhaustivo de este aspecto, pues no es el objetivo central del artículo, e implicaría un aumento considerable en la extensión del mismo. Se señalan, por tanto, los rasgos significativos para el objetivo perseguido: identificar la autoría del manuscrito.

${ }^{6}$ Son muchos los trabajos que han tratado sobre estos temas; pueden verse, entre otros, Contreras (1995) y Martínez (2010).
} 


\subsubsection{Empleo de mayúsculas}

Inconstante y arbitrario se muestra en el empleo de las mayúsculas, si bien se observa una tendencia a escribir con letras capitales los antropónimos y algunos topónimos; dicha inestabilidad gráfica era normal dado que los textos manuscritos prácticamente no se hacían eco de las reglas ortográficas que la imprenta sí seguía (solo hay que echar un vistazo al facsímil de la primera edición de los Comentarios Reales para constatar lo dicho).

Lo arriba visto demuestra el gusto del autor de estos tres folios manuscritos por las grafías tradicionales, coincidiendo plenamente con los usos de la carta autógrafa de Ávila. Hay que tener en cuenta, asimismo, que era poco habitual en la época en la que se escribe el texto y en su entorno sociocultural la preferencia por usos ortográficos tan conservadores.

\subsection{Algunos aspectos fonético-fonológicos del resumen de los "Comentarios Reales"}

Uno de los aspectos más importantes relacionados con los cambios fonéticofonológicos americanos atañe al resultado de las medievales sibilantes $|\mathrm{s} /-| \mathrm{z}|,| \hat{\mathrm{s}} /-|\hat{\mathrm{z}}|,|\check{s} /-| \check{z} \mid$ que parece comienza su camino hacia la simplificación ya en el siglo XIV. A América llegó un contingente de hablantes con diferentes realizaciones, desde aquellos que llevarían el proceso simplificador en marcha todavía, a otros que portarían ya los resultados actuales. De modo que se diseminaron arbitrariamente por tierras americanas todo tipo de realizaciones, desde aquellas minoritarias que podrían conservar todavía las diferencias entre sordas y sonoras hasta otras en las que el resultado fuera ya el actual en su variante norteña o meridional, pasando por realizaciones intermedias (Lapesa 1991: 563 y ss.). Naturalmente, a ello hay que agregar el proceso de nivelación producido desde muy pronto en el Caribe, donde parece que se formó una primera koiné en la que influyó de manera decisiva la solución simplificadora andaluza, ya que fueron muchos los hablantes de dicha procedencia que participaron en la conquista y repoblación de América?. Rivarola atribuye la simplificación de sibilantes de orden alveolar y dental a un proceso de generalización en el marco de una reestructuración patrimonial del castellano que estuvo en el origen de la formación y difusión del español en América (Rivarola 2001; 2002) ${ }^{10}$.

\footnotetext{
${ }^{7}$ No se pretende ofrecer un estudio exhaustivo de este aspecto, pues no es el objetivo central del artículo, e implicaría un aumento considerable en la extensión del mismo. Se señalan, por tanto, los rasgos significativos para el objetivo perseguido: identificar la autoría del manuscrito.

${ }^{8}$ Sobre el proceso de koineización, véanse Rosenblat (1967), Fontanella (1993) y Granda (1994).

${ }^{9}$ No hacía mucho tiempo que Andalucía había sufrido también un proceso de simplificación al recibir gentes de distintas procedencias peninsulares, debido también a la conquista y posterior repoblación de la zona (Frago 1993). Peter Boyd-Bowman $(1968 ; 1976)$ demuestra en sus últimos estudios la destacada presencia de gentes llegadas a América procedentes del mediodía peninsular.

${ }^{10}$ Las pruebas documentales de la existencia del seseo aparecen en América desde muy pronto, por ejemplo, el estudio de Olga Cock (1969) sobre documentos de Nueva Espańa entre los años 1550 y 1650 muestra que los
} 
Sabido es que el análisis de la ortografía del manuscrito deja traslucir algunos rasgos del fonetismo practicado por el hablante; si nos fijamos en las grafías que servían para representar a las antiguas sibilantes medievales, vemos que los lapsus calami advierten sobre la simplificación de las mismas, en todos los órdenes y destaca, asimismo, la simplificación entre la articulación ápico-alveolar y la predorsodentoalveolar, lo que produce cacografías seseo-ceceosas que no permiten asegurar el timbre seseante, çiçeante o ceceante del autor (nasión 61v. y casiques 62r., etc.), pero asegura su simplificación. Este rasgo de simplificación se produce en la carta autógrafa del Padre extirpador de idolatrías, en el "Tratado y relación...", así como en el resumen de los Comentarios Reales.

Nada se puede deducir, en el análisis de estos tres folios, de la aspiración del sonido [h] procedente de F- latina ni se puede asegurar que existiera aspiración de la velar, si bien alguna corrección podría señalar la existencia de la misma, y no de su aspiración. En concreto, la corrección que realiza en el término higo 'hijo' 62r., donde corrige $g$ por $j$, si bien en absoluto es determinante, pues conocida es la inestabilidad gráfica que afecta a estas letras.

Cabe señalar, como rasgos de segundo orden, confusiones de nasales en nombres propios como el apellido Bustinca frente a Mustincia en los Comentarios Reales, el empleo sistemático de la forma muncho por mucho, que se trata, simplemente, de una extensión de la nasalidad inicial, la cual durante el siglo XVI estuvo muy extendida y fue de uso frecuente, por ejemplo, en los escritos del Padre Las Casas (DCECH, s.v.), pero ya en retroceso, o el debilitamiento de la $r$ implosiva en el infinitivo pará 'parar' de "fueron a pará», fol. 61r., grafiada una tilde sobre su á. Los rasgos fonético-fonológicos que acabo de señalar, procedentes de los manuscritos del resumen, coinciden, como hemos visto en el caso de los ortográficos, con los apreciados en la carta autógrafa del Padre de Ávila.

\section{La hutoría intelectual del resumen de los Comentarios Reales}

Pocas dudas caben respecto de la autoría gráfica del resumen: hemos visto que existen pruebas paleográficas, ortográficas e incluso, de manera coadyuvante, fonéticas que permiten asignar al Padre visitador de idolatrías la escritura del resumen analizado. Igualmente se dan otros indicios que me llevan a atribuir la autoría intelectual del resumen a Francisco de Ávila, más allá del hecho de que dicho resumen se encuentre entre los manuscritos del Ms. 3169 BNE. Por ejemplo, ya he indicado que el autor del resumen excluye del mismo una de las obras mencionadas por el Inca Garcilaso: la Repúblicas del mundo del padre agustino fray Jerónimo Román y Zamora, obra de la que, por otra parte, se halló en su biblioteca la nada desdeñable cantidad de 44 tomos $^{11}$. ¿ Se trata de un olvido? Podría ser, pero me parece poco

indígenas y criollos de la región emplean ya un sistema simplificado hacia el seseo. Elena Rojas (1984) demuestra esta misma circunstancia para el caso del español de Tucumán y Beatriz Fontanella (1992) para Buenos Aires.

${ }^{11}$ Es decir, como señaló Hampe (1996), si se trataba de la edición en 3 volúmenes, como la que queda registrada 
probable, pues hay razones históricas que apuntan a que dicha ausencia se podría deber a un acto consciente del Padre visitador de idolatrías. Recordemos que la Corona, en cédula despachada en Madrid en 1575, mandó recoger la obra del agustino Jerónimo Román y Zamora, ya que trataba «muchas cosas en deshonor de los primeros conquistadores y poniendo en dubda en el señorío, y otras cosas indecentes e insolentes» (Zavala 1988). Más tarde circuló censurada, esto es, con partes de la misma tachadas, tal y como han llegado hasta nosotros muchos de los ejemplares que se conservan. Sin duda, en dichas condiciones, censurada, llegó al Perú el ejemplar que, junto con los Comentarios Reales y otras obras, trajo consigo el fiscal del Perú, Cristóbal Cacho. No puede ser casual dicha exclusión, sino que se debe, muy probablemente, a la censura propia de quien debió de haber recogido en su biblioteca, siguiendo la orden real, más de 15 colecciones completas de dicha obra, esto es, Francisco de Ávila. ¿Qué otra cosa podía hacer en su biblioteca una cifra tan elevada de dicha publicación? Y recordemos que su biblioteca no se caracteriza por la acumulación de ejemplares de ninguna otra obra. Es natural que la Corona temiera que la recién nacida sociedad hispanoamericana, formada por indígenas, españoles, mestizos y criollos, leyera obras que pudieran poner en duda su autoridad. El propio Ávila asegura que ya en su época era habitual que los indígenas leyeran este tipo de obras: «Y es mucho de notar que estos indios que assí acuden a esto/ ${ }^{9}$ ay muchos muy ladinos y entendidos y que saben leer $\mathrm{y} /{ }^{10}$ escrebir y se an criado con españoles y sacerdotes $(/)$, y otros son $/{ }^{11}$ cantores de las yglesias y maestros de capilla $(\ldots)^{/ 12}{ }^{\prime}, A G I$, Lima, 301 , fol. 4r. Nada extraño hay en ello, pues ya en el Cuzco de la última veintena del siglo XVI había en cada parroquia un notario indígena que se ocupaba de dar fe pública de las actividades privadas de sus vecinos, lo que pone de manifiesto el alto grado de hispanización de la población indígena cuzqueña, que conservaba, no obstante, las tradiciones que no chocaban con la cultura cristiana occidental de la época (Navarro 2007 y 2015). La citada exclusión de las Repúblicas del mundo no carece de relevancia, pues permite vincular la decisión de no incluir esta obra, junto con las razones históricas aducidas, con el carácter de hombre respetuoso con las cosas de dios y de la Corona que parece guiaba la vida del extirpador de idolatrías en la época en la que se escribió el resumen ${ }^{12}$.

en el inventario de su biblioteca, estaríamos hablando de 15 colecciones completas. Esto viene a confirmar que, ciertamente, esta obra debió de ser muy leída.

${ }^{12}$ La lectura de los textos escritos por Francisco de Ávila pone de manifiesto un aparente cambio en sus ideas. De hecho, desde 1608, fecha en la que comenzó a escribir su "Tratado y relación de errores...", hasta aproximadamente 1648, año probable de finalización de su "Tratado de los Evangelios", se observa un cambio importante en el tratamiento y consideración que le merecen indígenas y autoridades. Si en la primera obra realiza largas digresiones de áspero tono contra el modo de proceder de los indígenas: "Pues quién no vee la gran ceguedad desta miserable gente, y a quién no dieren el poco fruto que entre ellos ha hecho la predicación y verdad Cathólica después de tantos años de que ni pueden pretender ignorancia ni quexarse de que no son ensańados...", fol. 6r., en sus sermones, escritos muchos ańos después, muestra un mayor compromiso con los naturales y un alto grado de crítica a la situación político-social de la época, pues en ellos llega a predicar simultáneamente la resurrección de los incas y la posibilidad de que el rey de Espańa pudiese perder el Perú. Sobre los sermones del Padre de Ávila véase Estensoro (2003: 360). La elección de una obra comedida y conciliadora 


\section{LOS MOTIVOS QUE PUDIERON LLEVAR A LA REALIZACIÓN DEL RESUMEN DE LOS COMENTARIOS REALES}

A la luz de las pruebas aducidas no parece que quepa alguna duda sobre la autoría intelectual y gráfica del resumen citado. Queda no obstante intentar dilucidar las causas que pudieron motivar la ejecución del mismo y su vinculación con el resto del manuscrito que compone el Ms. 3169. Para ello debemos partir de los acontecimientos históricos en que se gestó el resumen, así como de la información que podemos extraer de los manuscritos que integran el mamotreto antes mencionado. Dicho conocimiento, como veremos, puede verse reforzado por el resultado del análisis discursivo del resumen.

\subsection{Aspectos lingüistico-discursivos del resumen aviliano: el discurso referido}

Es conocida la complejidad discursiva que presenta la obra fuente de este resumen, esto es, los Comentarios Reales de Garcilaso. En este célebre texto encontramos: autobiografía, narración histórica, descripción etnográfica, traducción, etc.; por ese motivo ha sido calificada, con acierto, de obra coral (Mazzotti 1994). El resumen realizado por Francisco de Ávila se encuadra, en principio, como tipo textual, entre lo que hoy llamaríamos reseña "Noticia y examen de una obra literaria o científica" y recensión "Estudio y jerarquización de los testimonios de una tradición textual” (DRAE, s.v.), pues el padre de Ávila realiza una selección que implica jerarquización de contenidos que habían sido previamente extraídos de una tradición textual -la propia del texto garcilasiano-, que a su vez se había nutrido de diversas fuentes tanto orales como escritas. Hemos visto que el autor del resumen no duda en ańadir a este complejo textual polifónico lo que cree relevante ni en rectificar lo que considera erróneo, a fin de mejorar la historia que narra el texto original. He aquí una labor intelectual, que va más allá del mero resumen.

Qué duda cabe de que todo texto remite a otro u otros textos anteriores. En la intertextualidad se plantea, en primer lugar, el problema de la tipología: es fundamental el establecimiento de la clase de texto que el autor quiere hacer, esto es, ha de decidir qué tipo textual conocido se adecua mejor a sus intereses. Pero, en segundo lugar, se plantea el problema de la «alusión textual», que son "las maneras en que los comunicadores hacen referencia o utilizan textos conocidos» con respecto a los cuales tienen que establecer una «distancia temporal» y un "nivel de mediación» o intervención subjetiva del texto que cita en el texto citado (Beaugrande \& Dressler 1997: 225). En el caso que nos ocupa la intertextualidad se hace explícita en un discurso que podríamos calificar también de macrocita, cuyo marco se establece al final de la misma, cuando Ávila escribe: “Todo esto es sacado del libro de los comentarios Reales de Garcilaso de la vega, primer tomo que contiene 9 libros". A lo que le sigue la fecha en la que realiza dicha síntesis: "Escreuilo en primero de junio 1613", fol. 63v.

como la del Inca Garcilaso para realizar su recensión parece responder a un paso intermedio entre ambas posturas. 
El carácter polifónico del texto que sirve de fuente a dicho resumen, así como el propio resumen, nos lleva a considerar, siquiera brevemente, los mecanismos lingüísticos que sirven para reproducir la voz de otros. Nos vamos a centrar ahora en las citas explícitas o enunciados de discurso referido. En la cita explícita nos encontramos siempre con un texto que cita y otro que es citado; y en ellos hay que atender, por una parte, a la enunciación (el discurso) y al enunciado y, por otra, a la inclusión del texto citado en el texto que cita y al comentario del texto que cita sobre el texto citado. En el análisis de la intertextualidad, como señala Girón Alconchel, la relación de sintaxis y discurso es muy relevante, de modo que las formas del discurso referido se identifican con esquemas sintácticos, si bien se corresponden con una unidad superior (Girón Alconchel 2000; 2002). La cita explícita se sirve de la subordinación sustantiva, la yuxtaposición y la combinación de ambas construcciones como esquemas sintácticos. Así considera Girón Alconchel que la subordinación sustantiva origina el discurso indirecto; la yuxtaposición, el discurso directo; y la combinación o mezcla de una y otra, el discurso indirecto libre (Girón Alconchel 1989). Es posible que estos discursos aparezcan en un mismo enunciado dando forma a lo que llama dicho investigador un enunciado pluriforme de discurso referido o que aparezca solo uno de ellos, enunciado uniforme.

Los folios avilianos de los Comentarios Reales del Inca Garcilaso, pese a su simplicidad sintáctica (la cohesión del texto es fundamentalmente léxica y predominan las oraciones simples) son una interesante muestra de cómo el análisis de la intertextualidad sintáctica puede dar pistas relevantes sobre el objetivo, no formulado por su autor, de un texto.

Los tres folios avilianos están enmarcados en una variante de discurso referido exclusiva de la exposición didáctica, que relaciona tradiciones discursivas y variación del discurso referido. Califica Girón estos casos como paráfrasis de discurso directo y lo explica de la siguiente manera: "El discurso reproducido no ofrece ni rasgos distintivos ni indicios internos específicos de la mención indirecta o directa, porque el locutor hace suyo el enunciado, pero al mismo tiempo, lo enmarca como una cita de DD" (Girón 2008). Véase el siguiente ejemplo: "ca en todas las virtudes, los medios son loados, e Della los estremos, siempre serán tachados; así lo ponen filósofos e todos los letrados" (Rimado de Palacio $347 \mathrm{abc}$ ). Es evidente que el recurso del que se sirve Ávila es el mismo, si bien en este caso el discurso directo es una narración de tres folios, recto y vuelto, que contiene, a su vez, otras formas del discurso referido propias de los textos cronísticos. Además, hay que tener en cuenta que la obra fuente reproduce, a su vez, muchos otros discursos: «lo que -según su autor- oyó a los suyos sobre su antigua tradición», además de otros textos, escritos antes que los Comentarios, algunos de ellos hoy desaparecidos.

El resumen aviliano no posee título alguno, comienza directamente, a modo de discurso directo:

Año (.) de 1484 (.) Alonso sánchez de Huelua, natural de la uilla de/1 Huelua, en el condado, tenía contratación a las canarias desde/2 sevilla (.) y de canarias a la ysla de la madera. Lleuó vn temporal, sin poder/3 rosistir, a vna ysla que fue la de Santo Domingo. (.) Saltó allí, tomó el sol, (.) des-/4 cribió la tierra. (.) Boluió», 61r. y 
termina enmarcado por las siguientes palabras: «Todo esto es sacado del libro de los comentarios Reales de/34 Garcilaso de la vega, primer tomo que contiene (.) 9 (.) libros./35 Escreuilo (-) en primero de junio/36 ( $) 1613(\neg) . / 37$, fol. 63v.

Esta aparente macrocita sirve para transmitir el saber compendiado en la crónica escrita por el Inca Garcilaso, pero, además, Ávila realiza un cotejo de esta con los conocimientos que él mismo posee en el momento de realizar su escrito, de modo que dicha macrocita tiene una finalidad que se podría calificar como didáctico-intelectual. ¿Qué finalidad podía tener el selectivo resumen que realiza Ávila y que escribe a continuación de la copia realizada de unos papeles sobre los incas que guardaba Polo de Ondegardo? El objetivo pudo ser contribuir a los planes de la Corona espańola en cuanto a la redacción de una historia, bien documentada y que gozara de la aprobación oficial, sobre la forma de gobierno y la historia de los incas, planteada esta como un continuum histórico.

Obviamente, dentro de la macrocita, el discurso se articula a través de diferentes formas del discurso referido, discursos que en contadas ocasiones se corresponden literalmente con su fuente. En lo fundamental, emplea construcciones sencillas: junto al discurso directo, los discursos indirecto, narrado e indirecto libre, pero en ocasiones se sirve también de enunciados pluriformes de discurso indirecto y discurso indirecto libre, que son los de sintaxis más compleja. Veamos, a continuación, algunos ejemplos de las diferentes formas del discurso referido utilizadas en esta macrocita.

Para realizar su resumen prefiere Ávila el discurso indirecto:

1. [Viracocha] le hizo entender (discurso que cita) que las mantas y piedras se boluían hombres contra el capitán chanca, (discurso citado)

2. El viracocha y le dixo (discurso que cita) que se preuiniesse su padre para una cruel guerra que se le auía de levantar (discurso citado), fol. 62v.

En el siguiente ejemplo observamos cómo el discurso indirecto y el discurso indirecto libre conviven en un mismo párrafo:

3. Otros dizen (discurso que cita) que, después que cesaron las aguas del diluuio, pareció un poderosíssimo hombre de tiahuanco, que es ysla de la laguna Titicaca (discurso citado) (discurso indirecto), y este tuuo cuatro hijos (discurso indirecto libre), fol. 61v.

Véase un ejemplo de cómo se narra este mismo hecho por la fuente, esto es, en los Comentarios Reales del Inca Garcilaso:

Dizen que passado el diluuio, del qual no saben dar mas razon de decir que lo huuo, ni se entiende si fue el general del tiempo de Noe (...) dizen pues que cessadas las aguas se apareció vn hombre en Tiahuacanu, que esta al medio dia del Cozco, que fue tan poderoso que repartio el mundo en quatro partes, $y$ las dio a quatro 
hombres que llamo Reyes, Primera Parte, capítulo XVIII.

El discurso narrado también menudea en el resumen:

4. $6^{\circ}$ (.) Rey Ynca (.), llamado yncaroca (...) Este Ynca enbió a conquistar a antisuyu/9 a su hijo yahuarhuacac, fol. 62r.

5. El cuerpo deste [Viracocha] halló el licenciado Polo ondegardo(.),/5 año (.) de 1560 (.), y el cuerpo de Tupac ynca yupanqui, bisnieto de viracocha, ${ }^{6}$ el $3^{\circ}$ Huaynacapac, hijo de Tupac ynca (-), y el cuerpo de mamaruntu, $/^{7}$ mujer del viracocha (-), la otra coyamama (.) ocllo, madre de huaynacapac, fol. 62v.

Se suceden en los siguientes ejemplos el discurso indirecto junto al discurso indirecto libre y el discurso narrado:

6. Estas villas se preciaua (discurso que cita) de que las ánimas de sus pueblos salieron de una laguna (discurso citado) (discurso indirecto) y en muriendo (discurso indirecto libre), fol. 61v.

7. Dezían que assí como el viracocha se apareció ante ynga $\left(8^{\circ}\right)$ para favorecer contra los chancas, assí los españoles vinieron a favorecer a Huáscar ynca contra Atahuallpa, su hermano, y por ser favorecedores como él (discurso indirecto libre), el otro lo llamaron viracocha (discurso narrado), fol. 62r.

En este resumen de solo tres folios hemos visto cómo Francisco de Ávila utiliza todos los recursos lingüísticos descritos hasta ahora por la crítica para reproducir las voces de otros. De un lado, dentro del propio resumen se observan abundantes variantes del discurso referido con preferencia clara por las formas más sencillas, es decir, las que entrañan una menor complejidad sintáctica. De otro lado, el propio resumen obedece a un tipo de variante del discurso referido propia de las citas de carácter didáctico-intelectual que nos permite vislumbrar la finalidad con la que fue escrito.

\subsection{La unidad temática del Ms. 3169 de la Biblioteca Nacional de España}

La unidad temática que presentan los manuscritos que componen el mamotreto aviliano parece encerrar un propósito de mayor alcance que su mera recopilación. De hecho, la temática de los manuscritos junto a la intención revelada por el padre de Ávila de volver a escribir ${ }^{13}$ el "Tratado y relación de los errores, falsos dioses ..." ponen de manifiesto, a mi

\footnotetext{
${ }^{13}$ Son muchas las indicaciones que realiza el padre de Ávila a lo largo del inconcluso tratado o fábula: «Capítulo $3^{\text {o }}$ de vn eclypse de sol que dizen que uuo antiguamente en toda esta historia y fábulas no he podido aueriguar el orden y su ocassión de ellas quál fue primer y quál después ... más podrá ser que para quando esto se buelua a escreuirlo tenga sabido o a lo menos lo más verisímil ... Necessario es boluer el passo atrás en este capítulo o que esto sea el $3^{\circ}$ y el precediente el quarto» fol. 64v., Navarro (2007).
} 
entender, un plan más complejo y amplio que podría cifrarse en el intento de escribir una historia sobre los orígenes del Perú. Dicho propósito se puede poner en relación, a su vez, con el proyecto que trasladó la Corona española al virrey Toledo y que, sin duda, era más abarcador que el que parece tener Ávila, pues se pretendía:

1. La descripción geográfica de la tierra ${ }^{14}$.

2. Los ritos, las idolatrías y gobierno que tuvieron los pueblos indígenas antes de formar parte del imperio inca.

3. La descripción de las conquistas, gobierno, jerarquía, etc., de los incas durante todo su gobierno.

Estos dos últimos aspectos debían fundamentarse en pruebas, pues se estableció que la información estuviera basada en los relatos de los propios indígenas. Las razones de tal tarea tenían que ver con la necesidad de la Corona de conocer el territorio que debía gobernar, así como demostrar el derecho que le asistía a la posesión de las tierras del Perú. Si observamos el contenido de las obras que componen dicha colección de manuscritos comprobaremos que apunta, claramente, en la misma dirección. Recuérdese, por ejemplo, la Relación de Pachacuti Yamqui; en ella su autor, indígena hispanizado, presenta a los primeros conquistadores de Perú como aquellos hombres que ayudaron al legítimo inca Huáscar a deshacerse del dominio y usurpación al que lo tenía sometido su medio hermano Atahualpa, trayendo consigo el evangelio que permitiría el nacimiento de una nueva estirpe de hombres, indoamericanos principales cristianizados. También se ve favorecido el interés de la Corona por conocer la realidad americana en el "Tralado de un cartapacio a manera de borrador que quedó en los papeles de el Licenciado Polo de Ondegardo Cerca de el linaje de los ingas y cómo conquistaron", fols. 37-63, que trata, asimismo, sobre los incas y su imperio, y no olvidemos que Ondegardo colaboró estrechamente con el virrey Toledo. Aunque en menor medida, colaboró, igualmente, con el virrey el padre Molina, de quien hallamos en este mamotreto "La Relación de las fábulas y ritos de los incas", fols. 2-36; obra que, aunque no fue escrita para el Virrey, responde claramente, asimismo, a los intereses de Toledo $^{15}$.

Recuérdese que desde 1575 todos los oficiales reales americanos estaban obligados a hacer llegar al Cronista y Cosmógrafo oficial relaciones y noticias sobre América. En 1636 se amplió dicha obligación a "qualquier persona particular" que tenga noticias o posea

\footnotetext{
${ }^{14}$ Se realizaron no pocas descripciones geográficas, parciales, del virreinato del Perú desde el siglo XVI. Dicha tarea culminó con la descripción geográfica del virreinato del Perú del ilustrado Cosme Bueno. Sobre este tema pueden verse, entre otros, Bravo-García \& Cáceres-Lorenzo (2013).

${ }^{15}$ Nótese que el virrey Toledo se rodeó de un nutrido y excepcional grupo de especialistas tanto religiosos como laicos para ser asesorado en sus decisiones; de ellos destaco nombres tales como el oidor de Lima González de Cuenca, Matienzo, el licenciado Polo de Ondegardo, Ruiz de Navamuel, el dominico fray García de Toledo y el jesuita padre José de Acosta. A su vez, estos consejeros contaron con la colaboración de hombres de la talla y experiencia de Sarmiento de Gamboa o el padre Cristóbal de Molina, por poner solo algún ejemplo (Baylle 1952).
} 
papeles, relaciones, escritos, etc., para que saquen copia o que las entreguen al Cronista y Cosmógrafo oficial de la Corona (Brendecke 2016: 416). En principio los manuscritos de Francisco de Ávila, especialmente las copias de Molina y Polo de Ondegardo, por la cercanía ideológica de sus autores al virrey Toledo, podrían responder bien a los requerimientos de la Corona, pero lo lógico es pensar que ya se habían encargado ellos mismos, hacía tiempo, de cumplir con la obligación de enviar los originales o copias a España. El que el padre de Ávila mandara realizar dichas copias, así como la recopilación de la relación quechua y su traducción, la obra del indígena Joan Santa Cruz Pachacuti y, sobre todo, el resumen de una parte de la obra del insigne mestizo peruano, con los ańadidos y elisiones antes vistos, hacen pensar que el principal objetivo de dicha recensión no fue el de dar a conocer, sin más, la obra del humanista mestizo, sino el deseo de reelaborar a partir de los materiales seleccionados una historia de los orígenes del Perú. La decisión del Padre de Ávila de elegir para su resumen la variante de discurso referido exclusiva de la exposición didáctica, ampliada aquí al terreno intelectual por los significativos cambios que efectúa en ella, sitúa el texto que escribe como antecedente del tipo textual recensión, a la vez que nos permite vislumbrar el motivo que pudo llevar a Ávila a escribir los tres folios aquí analizados, y que parece no ser otro sino el proyecto de componer una historia, que a la manera de las grandes crónicas medievales, habría contado con distintos traductores ${ }^{16}$ y numerosas fuentes, entre las que se encontraría la obra del Inca Garcilaso, los Comentarios Reales ${ }^{17}$.

\section{Conclusión}

El resumen de los Comentarios Reales del Inca Garcilaso, finalizado por su autor en junio de 1613, pone de manifiesto que la obra del insigne cuzqueño había llegado, en un corto plazo de tiempo, al Perú. Se sabe que a mediados o finales de 1612 hubo de llegar un ejemplar de los Comentarios a manos del fiscal de Lima a la sazón, don Cristóbal Cacho de Santillana, pero ignoramos si se trata del ejemplar que utilizó el autor del resumen. Es esta una sugerente posibilidad que ha de quedar, por el momento, en el terreno de la mera hipótesis especulativa. La ausencia de noticias sobre el envío de ejemplares a América no significa, ni mucho menos, que la obra no llegara, pues hay que considerar, asimismo, que pudo arribar en forma manuscrita y de esta forma extenderse por el Nuevo Mundo. Efectivamente, la circulación en forma manuscrita de obras que habían sido impresas fue habitual no solo durante los primeros años de la invención de la imprenta, sino mucho

\footnotetext{
${ }^{16} \mathrm{El} \mathrm{"Tratado} \mathrm{de} \mathrm{los} \mathrm{ritos} \mathrm{y} \mathrm{falsos} \mathrm{dioses..."} \mathrm{de} \mathrm{Francisco} \mathrm{de} \mathrm{Ávila,} \mathrm{en} \mathrm{su} \mathrm{folio} \mathrm{13v.} \mathrm{demuestra} \mathrm{que} \mathrm{las} \mathrm{traducciones}$ del quechua al castellano no las realizaba únicamente el Padre de Ávila, sino también otros traductores que, dado el laísmo que practica uno de ellos en el folio señalado, podían ser de origen peninsular, sin excluir, claro es, la ayuda de mestizos y naturales.

${ }^{17}$ Se han hallado claros indicios de la existencia de talleres de trabajo en los que se realizaba una composi-ción colectiva (el caso de la Relación de Michoacán), con participación de frailes e indígenas. Véase Stone (1999).
} 
tiempo después, incluso, de la época que nos ocupa.

Se ha pretendido demostrar, a lo largo de estas páginas, adoptando una perspectiva interdisciplinar, que el autor del resumen de los Comentarios Reales del Inca Garcilaso, incluido en el manuscrito 3169 de la BNE, es Francisco de Ávila. Hemos comprobado, a través del estudio paleográfico ${ }^{18}$ de las grafías de los tres folios de los que consta el manuscrito del resumen que, pese al polimorfismo habitual en el autor y en la época a la que pertenece el manuscrito, las grafías de este se corresponden con las analizadas en la carta escrita y firmada por Francisco de Ávila, así como con las páginas que, analizadas a la luz de dicha carta, se pueden atribuir, fácilmente, también a su pluma, esto es, la primera página de las relaciones de Molina y Ondegardo, buena parte del inconcluso "Tratado y relación..." de Ávila y algunas notas al margen de las copias antes citadas y de la relación de Joan de Santa Cruz.

La ortografía ha apoyado, asimismo, la autoría aviliana del texto. En efecto, hemos podido comprobar que los usos se asemejan de manera absoluta: el empleo de -ss- en el imperfecto de subjuntivo o de - $u$ - en el imperfecto de indicativo de manera sistemática, el frecuente uso de grafías dobles cultistas, etc. Asimismo, el estudio de la ortografía, tanto en los escritos atribuidos a Ávila como en el resumen, apunta en la misma dirección en aquellos casos en los que la grafía posee transcendencia fonético-fonológica, pues hemos hallado cacografías seseo-ceceosas que indican la simplificación de las sibilantes en una sola.

El contenido del resumen nos proporciona importantes pistas sobre su autoría intelectual, que van más allá de la mera inclusión en el grupo de manuscritos que estuvo en poder de Francisco de Ávila. Así, hemos visto que, inexplicablemente, guardaba en su biblioteca 44 volúmenes de las Repúblicas de mundo del agustino Román y Zamora y que esta obra en 1575 fue mandada recoger por la Corona española. Ambas circunstancias, puestas en relación, revelan que el padre de Ávila ejecutó diligentemente dicha orden y que su celo llegó hasta este resumen, del que excluye la mencionada obra.

El estudio lingüístico del resumen aviliano viene a reforzar las propias palabras de Ávila respecto de su intención de reelaborar su "Tratado y relación de falsos mitos y fábulas...", y permite apoyar la tesis de que Francisco de Ávila estaba pensando en elaborar una historia del Perú que incluyera los ritos, creencias y gobierno anterior a los incas, la conquista inca y sus leyes hasta enlazar con la conquista española. Es evidente que dicha finalidad didáctico-intelectual, oficialista o no, movió a Francisco de Ávila a realizar su resumen, una variante del discurso referido exclusiva de la exposición didáctica, que cumplía un papel importante en su proyecto de elaborar, al modo de las grandes crónicas medievales, una historia del Perú desde sus orígenes y conectada con la historia, al menos, europea.

Ya he señalado que se desconoce el alcance que pudo tener la recepción de la obra del Inca Garcilaso en Hispanoamérica, de modo que este trabajo contribuye, en alguna medida, a su esclarecimiento, pues demuestra que Francisco de Ávila (y lógicamente con él, su círculo cercano) no solo tuvo acceso a dicha publicación en época muy temprana (su pequeño texto es escrito en 1613), sino que su lectura le resultó de notable interés. La

${ }^{18}$ A la misma conclusión llega Martínez (2016). 
determinación de su autoría, junto al análisis de los manuscritos que forman parte de este legajo, nos ha permitido atisbar los motivos que pudieron llevar al Padre de Ávila a realizar dicho resumen, motivos que pudieron consistir en escribir una historia del Perú, basada, como vengo señalando, en fuentes legítimas, coincidiendo con la petición realizada por la Corona espańola. Que el autor del resumen sea el Padre extirpador de idolatrías no es cuestión baladí, habida cuenta de que, entre otras cosas, este hecho permite dejar de especular sobre la unidad o no de estos manuscritos y sobre la arbitrariedad de su agrupamiento. Queda claro que dicha recopilación no fue arbitraria ni ocasional, sino que respondía a una forma de trabajo intelectual, semejante al realizado en la Península en las grandes crónicas medievales y semejante, a lo que parece, a la elaboración de la Relación de Michoacán en México. Determinar la autoría de este resumen, que no está firmado, tiene, igualmente, un valor muy relevante para los estudios sobre el origen y configuración del español en América, pues nos permitirá estudiar los usos gráficos, tanto de las grafías con trascendencia fonética como de aquellas que no la tienen, pero que ofrecen información, entre otras cosas, sobre el prurito lingüístico del autor, así como analizar los usos lingüísticos y discursivos de los manuscritos de autoría aviliana. Esto posibilitará, tras un estudio exhaustivo de estos documentos, anclar convenientemente a un hablante adscrito a un estrato sociocultural y geográfico determinado, así como a un tiempo concreto, los fenómenos lingüísticos hallados. Cuestiones estas fundamentales para elaborar una historia del español en América, basada en fuentes documentales fiables.

\section{ObRas CITADAS}

Baylle, Constantino. 1952. Los cabildos seculares de la América española. Madrid: Ediciones Sapientia.

Beaugrande, Robert de \& Wolfgang Ulrich Dressler. 1997. Introducción a la lingüística del texto. Barcelona: Ariel.

Boyd-Bowman, Peter. 1968. Índice geográfico de cuarenta mil pobladores españoles de América en el siglo XVI, I (1493-1519), II (1520-1539). México: Jus.

Boyd-Bowmann, Peter. 1974. "La emigración española a América: 1560-1579". Studia hispánica in honorem R. Lapesa, II: 123-147.

Bravo-García, Eva \& M. Teresa Cáceres-Lorenzo. 2013. El léxico cotidiano en América a través de las Relaciones geográficas de Indias. Tierra Firme y América del siglo XVI. Bern: Peter Lang.

Brendecke, Arndt. 2016. Imperio e información. Funciones del saber en el dominio colonial español. Madrid/Frankfurt: Vervuert/Iberoamericana.

Cock Hincapié, Olga. 1969. El seseo en el Nuevo Reino de Granada: 1550-1650. Bogotá: Instituto Caro y Cuervo.

Contreras, Lidia. 1995. Ortografía y grafemática. Madrid: Visor.

DCECH: Corominas, Joan y Pascual, José Antonio. 1980-1991. Diccionario Crítico Etimo- 
lógico Castellano e Hispánico, V. III. Madrid: Gredos.

Duviols, Pierre. 1966. "Estudio biobibliográfico". En: Arguedas, José María. Dioses y Hombres de Huarochirí. Narración quechua recogida por Francisco de Ávila (¿1598?). Edición bilingüe. Lima: 218-271.

Estensoro, Juan Carlos. 2003. Del paganismo a la santidad. Lima: Pontificia Universidad Católica del Perú-IFEA.

Fontanella, Beatriz. 1992. "La evolución fonológica del español americano durante la etapa colonial”. Anuario de Lingüistica Hispánica 8: 85-97.

Frago, Juan Antonio. 1993. Historia de las hablas andaluzas. Madrid: Arco Libros.

García Cabrera, Juan Carlos. 1994. Ofensas a Dios, pleitos e injurias. Causas de idolatrías y hechicerías, Cajatambo, siglos XVII-XIX. Cuzco: Centro de Estudios Regionales Andinos "Bartolomé de las Casas".

García Cabrera, Juan Carlos. 2015. "El juicio contra Francisco de Ávila y el inicio de la extirpación de la idolatría en el Perú". En línea www.idolatrica.com (Consultado 19 de enero de 2015).

Girón Alconchel, José Luis. 1989. Las formas del discurso referido en el Cantar de mío cid. Madrid: Real Academia Española (Anejo xuIv del BRAE).

Girón Alconchel, José Luis. 2000. "Sintaxis y discurso en el español del siglo de Oro. Contribución a la historia del discurso indirecto libre". Voz y letra. Revista de Filología 9 (1): 93-113.

Girón Alconchel, José Luis. 2002. Discurso indirecto libre y autobiografía en la vida del Capitán Contreras. En: Carmen Saralegui \& Manuel Casado. Eds. Pulchre, bene, recte. Estudios en homenaje al Prof. Fernando González Ollé. Pamplona: EUNSA. 625-638.

Girón Alconchel, José Luis. 2008. "Tradiciones discursivas y gramaticalización del discurso referido en el Rimado de Palacio y las Crónicas del Canciller Ayala”. En: Kabatek, Johannes. Ed. Sintaxis histórica del español y cambio lingüistico: Nuevas perspectivas desde las Tradiciones discursivas. Madrid/Frankfurt: Iberoamericana/Vervuert. 173-186.

González Sánchez, Carlos Alberto. 2010. "Los Comentarios reales en la vida y el menester indiano del licenciado Cristóbal Cacho de Santillana (1599-1641)". En: Chang Rodríguez, Raquel. Ed. Entre la espada y la pluma. El Inca Garcilaso de la Vega y sus Comentarios reales. Lima: PUCP. 31-55.

Granda, Germán de. 1994. Español de América, español de África y hablas criollas hispánicas. Cambios, contactos y contextos. Madrid: Gredos.

Guibovich, Pedro. 1990-1992. "Lectura y difusión de la obra del Inca Garcilaso en el virreinato peruano (siglos XVII-XVIII): el caso de los Comentarios reales". Revista Histórica 37: 103-120.

Guibovich, Pedro. 2016. "La difusión del Inca Garcilaso de la Vega en los Andes". La biblioteca del Inca Garcilaso de la Vega. Madrid. Biblioteca Nacional de España. 49-62.

Hampe Martínez, Teodoro. 1996. Cultura Barroca y extirpación de idolatrías. La biblioteca de Francisco de Ávila. 1648. Cuzco: Centro Bartolomé de Las Casas.

Huamán Poma, Felipe. (h.1615) 1989. Nueua corónica y buen gobierno, edición facsímil. 
París: Institut d'Ethnologie.

Inca Garcilaso de la Vega. (1609) 2002. Comentarios Reales. Reproducción facsímil. Estudio de José Luis Rivarola. Madrid: Agencia Española de Cooperación Internacional.

Lapesa, Rafael. 1991. Historia de la Lengua Española. Madrid: Gredos.

López Parada, Esperanza. 2009. "Un relato mestizo del Inca Garcilaso: el caso transculturado del español pobre y la coca”. Revista de Crítica Literaria Latinoamericana 35 (70): 83-100.

Martínez Alcalde, María José. 2010. La fijación ortográfica del español: norma y argumento historiográfico. Bern: Peter Lang.

Martínez Sagredo, Paula. 2016. "Notas etnofilológicas sobre el volumen 3169 de la Biblioteca Nacional de España. Algunos aspectos sobre la escritura andina colonial". Boletín del Museo Chileno de Arte Precolombino 21 (1): 129-146.

Mazzotti, José Antonio. 1994. "Betanzos: de la 'épica' incaica a la escritura coral. Aportes para una tipología del sujeto colonial en la historiografía andina". Revista de Crítica Literararia Latinoamericana 40: 239-258.

Navarro Gala, Rosario. 2007. La Relación de antigüedades deste Reyno del Pirú. Gramática y discurso ideológico indígena. Madrid/ Frankfurt: Iberoamericana/Vervuert.

Navarro Gala, Rosario. 2012. El libro de protocolo del primer notario indígena (Cuzco, siglo XVI). Cuestiones filológicas, discursivas y de contacto de lenguas. Madrid/ Frankfurt: Iberoamericana/Vervuert.

Paz, Julián. 1933. Catálogo de manuscritos de América existentes en la Biblioteca Nacional. Madrid: Biblioteca Nacional de España.

Rivarola, José Luis. 2001. El español de América en su Historia. Valladolid: Universidad de Valladolid.

Rivarola, José Luis. 2002. "Sobre los orígenes y la evolución del Español de América”. En: Díaz, Norma; Ralph Ludwing \& Stephan Pfänder. Eds. La romania americanan: Procesos lingüisticos en situaciones de contacto. Madrid/Frankfurt: Iberoamericana/Vervuert. 33-48.

Rojas, Elena. 1984. "Acerca de las sibilantes en el español de Tucumán en los siglos XVI y XVII". Actas del III Congreso Internacional de Historia de la Lengua española. Madrid: Gredos. 535-543.

Rosenblat, Ángel. 1967. "Contactos interlingüísticos en el mundo hispanoamericano: El español y las lenguas indígenas en América”. Actas del Segundo Congreso Internacional de Hispanistas. 115-156.

Serrera Contreras, Ramón Ma; Luisa Vila Vilar \& Concepción Hernández-Díaz. 1999. El aragonés Cosme Bueno y la Descripción geográfica del Río de la Plata (1768-1776). Huesca: Instituto Estudios Altoaragoneses.

Stone, Cynthia. 1999. The Relación de Michoacán and the Reappropiation of Indigenous Traditions under Colonial. Norman: University of Oklahoma Press.

Taylor, Gerald. 2008. Ritos y Tradiciones de Huarochirí. Lima: Instituto de Estudios Peruanos. 
ESTUDIOS FILOLÓGICOS

Valcárcel, Daniel. 1951. Geografía del Perú Virreinal. Lima: Azángaro.

Weinrich, Harald. 1964. Estructura y función de los tiempos en el lenguaje. Madrid: Gredos.

Zavala, Silvio. 1988. Las instituciones jurídicas en la Conquista de América. $3^{\text {a }}$ edición revisada y aumentada. México: Editorial Porrúa. 